Review Article

\title{
Effects of IL-4-590C/T (rs2243250) Polymorphism on the Susceptibility of Smoking-Related Cancer: A Meta-Analysis Involving 11,407 Subjects
}

\author{
Guangyuan Chen $\left(\mathbb{D},{ }^{1}\right.$ Cong Hu $\left(\mathbb{D},{ }^{1}\right.$ Yuxuan Song $\left(\mathbb{D},{ }^{2}\right.$ Haifei Zhang $\mathbb{D}^{1},{ }^{1}$ Song Li ${ }^{D},{ }^{1}$ \\ Penghui Lai $\mathbb{i}$, ${ }^{1}$ Yiling Zhang $\left(\mathbb{D},{ }^{1}\right.$ and Peng Huang $\mathbb{C}^{3,4}$ \\ ${ }^{1}$ The Second Clinical Medical School, Nanchang University, Nanchang, Jiangxi 330006, China \\ ${ }^{2}$ Department of Urology, Tianjin Medical University General Hospital, Tianjin 300052, China \\ ${ }^{3}$ Center for Evidence-Based Medicine, School of Public Health, Nanchang University, Nanchang 330006, China \\ ${ }^{4}$ Jiangxi Province Key Laboratory of Preventive Medicine, School of Public Health, Nanchang University, \\ Nanchang 330006, China
}

Correspondence should be addressed to Peng Huang; huangpengncu@163.com

Guangyuan Chen, Cong $\mathrm{Hu}$, and Yuxuan Song contributed equally to this work.

Received 4 August 2019; Revised 5 October 2019; Accepted 5 November 2019; Published 2 December 2019

Academic Editor: Andrei Surguchov

Copyright ( 2019 Guangyuan Chen et al. This is an open access article distributed under the Creative Commons Attribution License, which permits unrestricted use, distribution, and reproduction in any medium, provided the original work is properly cited.

\begin{abstract}
Background. Several previous studies have assessed the relationship between IL-4-590C/T gene polymorphism and smokingrelated cancer in recent years; however, the results remain controversial. Based on it, the study intends to clarify whether IL-4$590 \mathrm{C} / \mathrm{T}$ variant increases the risk of smoking-related cancer through meta-analysis. Methods. We searched PubMed, EMBASE, Web of Science, Cochrane Library database, China National Knowledge Infrastructure, and Wanfang data information service platform to collect qualified case-control studies in strict accordance with the inclusion and exclusion standards. The 95\% confidence interval (95\% CI) and its odds ratio (OR) were adopted to access the relation between IL-4-590C/T gene polymorphism and smoking-related cancer; sensitivity analysis and publication bias assessment were carried out after the studies' quality evaluation. Results. 17 studies were included in total, with 5,061 patients and 6,346 control cases. A significant association between IL-4-590C/T variant and smoking-related cancer in total population was revealed in our meta-analysis results, and IL-4-590C/T variant might have a relatively protective effect on smoking-related cancer $(\mathrm{CT}$ vs. TT: $P=0.026$, $\mathrm{OR}=0.900,95 \%$ CI: $0.820-0.987)$. Subgroup analysis by ethnicity showed that the IL-4-590C/T polymorphism was associated with a decreased risk of smoking-related cancer in the Asian population (CTvs. TT: $P=0.008, \mathrm{OR}=0.878,95 \%$ CI: 0.798-0.967; CC + CT vs. TT: $P=0.030, \mathrm{OR}=0.903,95 \%$ CI: 0.824-0.990). Subgroup analysis based on types of cancer demonstrated the IL$4-590 \mathrm{C} / \mathrm{T}$ variant achieved a lower risk in renal cell cancer (CC vs. TT: $P=0.046, \mathrm{OR}=0.640,95 \%$ CI: 0.412-0.993). Conclusion. There is a conspicuous association between IL-4-590C/T polymorphism and decreased risk of smoking-related cancer, particularly in Asians. And IL-4-590C/T polymorphism may have a protective effect on renal cell cancer.
\end{abstract}

\section{Introduction}

Smoking is currently an important risk factor for a variety of cancers. Almost half of male urinary tumors and $1 / 3$ of female urinary tumors are caused by smoking [1]. Compared with nonsmokers, smokers can increase the prevalence of bladder cancer by two to three times [2]. Cigarette smoke itself is a rich free radical that induces DNA damage in cells by inducing it as a triggering factor for tumors. In addition, more than 60 carcinogens have been found in cigarette smoke, like aromatic amines, polycyclic aromatic hydrocarbons, and specific nitrosamines in tobacco; all of them are 
recognized as carcinogens in humans [3-5]. The genotoxic patterns of these chemicals have been delineated and related to the DNA damage in cells. DNA adducts can be caused by smoking [6], as a result of the formation of covalently bound DNA damage by the production of electrophilic substances. The formation of DNA adducts is a cancerous potential result, and DNA adducts can mislead DNA replication, resulting in mutations [7]. These specific genetic mutations affect critical areas that control cell function, which can lead to tumorigenesis [8]. Compared with individuals who smoke slightly, individuals who smoke heavily have a higher risk of cancer because of the higher concentration of carcinogens in their body $[9,10]$. The International Agency for Research on Cancer (IARC) has defined smoking-related cancer as the cause of cancers of the lung, oral cavity, gastric, bladder, and so on [11]. According to the latest cancer report of 2018, smoking-related cancers became a major public health problem with extremely high morbidity and mortality [12].

Interleukin-4 (IL-4) gene is oriented in the cytokine gene cluster on chromosome $5 \mathrm{q} 31-33$. It is a cytokine that can promote the proliferation of Th2 cells while inhibit the proliferation of Th1 cells, and finally reduce the immune response mediated by Th1 [13]. Many studies have shown that interleukin-4 can promote tumor progression and metastasis by affecting apoptosis of tumor cells [14-17]. At present, there have been several case-control researches to explore the relationship between IL-4-590C/T (rs2243250) gene polymorphism and smoking-related cancer, but the results are still controversial. The polymorphism of IL-4$590 \mathrm{C} / \mathrm{T}$ ( $\mathrm{rs} 2243250$ ) is a $\mathrm{C}$ to $\mathrm{T}$ base mutation, and the $\mathrm{T}$-allele gene means mutational allele gene and $\mathrm{C}$-allele gene means the wild allele gene. Our aim is to study whether the mutational T-allele and TT genotype increase the susceptibility of smoking-related cancer compared with $\mathrm{CT}$ and CC containing the wild C allele through systematic review and meta-analysis.

\section{Methods}

2.1. Literature Retrieval. We performed a comprehensive search of PubMed, EMBASE, Web of Science, Cochrane Library database, China National Knowledge Infrastructure, Wanfang data information Service platform, and manual search to find relevant studies. The English search strategy: (cancer or carcinoma or neoplasm) AND (IL 4 OR IL-4 OR Interleukin 4 OR Interleukin-4) AND (SNP or variant or polymorphism or genotype). We searched the studies published before Aug 1, 2019. At the same time, the corresponding literature, academic conference papers, and unpublished documents were included in the literature through manual search.

\subsection{Inclusion and Exclusion Criteria}

2.2.1. Inclusion Criteria. The inclusion criteria were as follows: (1) case-control articles about the polymorphism of IL-4 referring to smoking-related cancers; (2) the studies including IL-4-590C/T (rs2243250) variant; (3) studies having sufficient data for examining the odds ratio (OR) with 95\% confidence intervals (CIs); (4) the articles reporting the risk of smoking-related cancers which were defined according to the IARC monograph; (5) the genotypes accorded with Hardy-Weinberg equilibrium (HWE).

2.2.2. Exclusion Criteria. The exclusion criteria were as follows: (1) the control group gene distribution contained in these studies was not subject to HWE; (2) literature with incomplete data or data not available.

\subsection{Literature Quality Evaluation and Data Extraction.} The quality of the included literature was accessed using the evaluation criteria of the case-control study in the Newcastle-Ottawa scale (NOS). The evaluation included (1) the selection of study subjects, (2) the inter-group comparability, and (3) the exposure evaluation. The NOS divides the quality of the literature into $0-9$ points. The higher the score, the better the quality of the literature. The score $\geq 5$ is considered to be a literature of high quality.

The data extraction includes the studies' names, the publication year, the target country, the race, the cancer type, the amount of case group and control group, and its genotype distribution and genotyping methods.

2.4. Statistical Methods. Meta-analysis was performed using Stata12.0 software. Q test and heterogeneity coefficient $I^{2}$ were used to judge the heterogeneity between studies. If there is statistical heterogeneity $\left(I^{2}>50 \%\right.$, or $\left.P<0.1\right)$, the random effect model is used for meta-analysis; otherwise, the fixed-effect model is used. Using odds ratio (OR) as an effector to reflect the strength of the correlation between IL-4 rs2243250 and smoking-related cancer. And we included five models: (1) allele model, (2) dominant model, (3) codominant model, (4) homozygote model, and (5) recessive model, to analyze the association, respectively. The $\mathrm{T}$ allele is a mutational allele, and the $\mathrm{C}$ allele is a wild allele. In addition, the heterogeneity source was explored by subgroup analysis. And the $P$ value of Egger's test, Begg's test, and funnel chart was obtained to evaluate the bias induced from publication.

\section{Results}

A total of 1,324 potentially relevant researches were identified in accordance with the search strategy (Figure 1). Ultimately, 17 case-control articles were selected into our meta-analysis.

3.1. Traits of the Selected Studies. The traits of the selected studies are presented in Table 1. For IL-4 rs2243250 polymorphism, 24 articles were investigated. However, deviations from HWE were found in 7 articles [18-24], so we have to remove these 7 articles (Figure 1), while the other 17 articles were in accordance with HWE. Of these 17 articles [25-41] (including 5,061 cases and 6,346 controls), seven studied the relation between IL-4-590C/T variant and the susceptibility of gastric cancer, three between IL-4-590C/T 


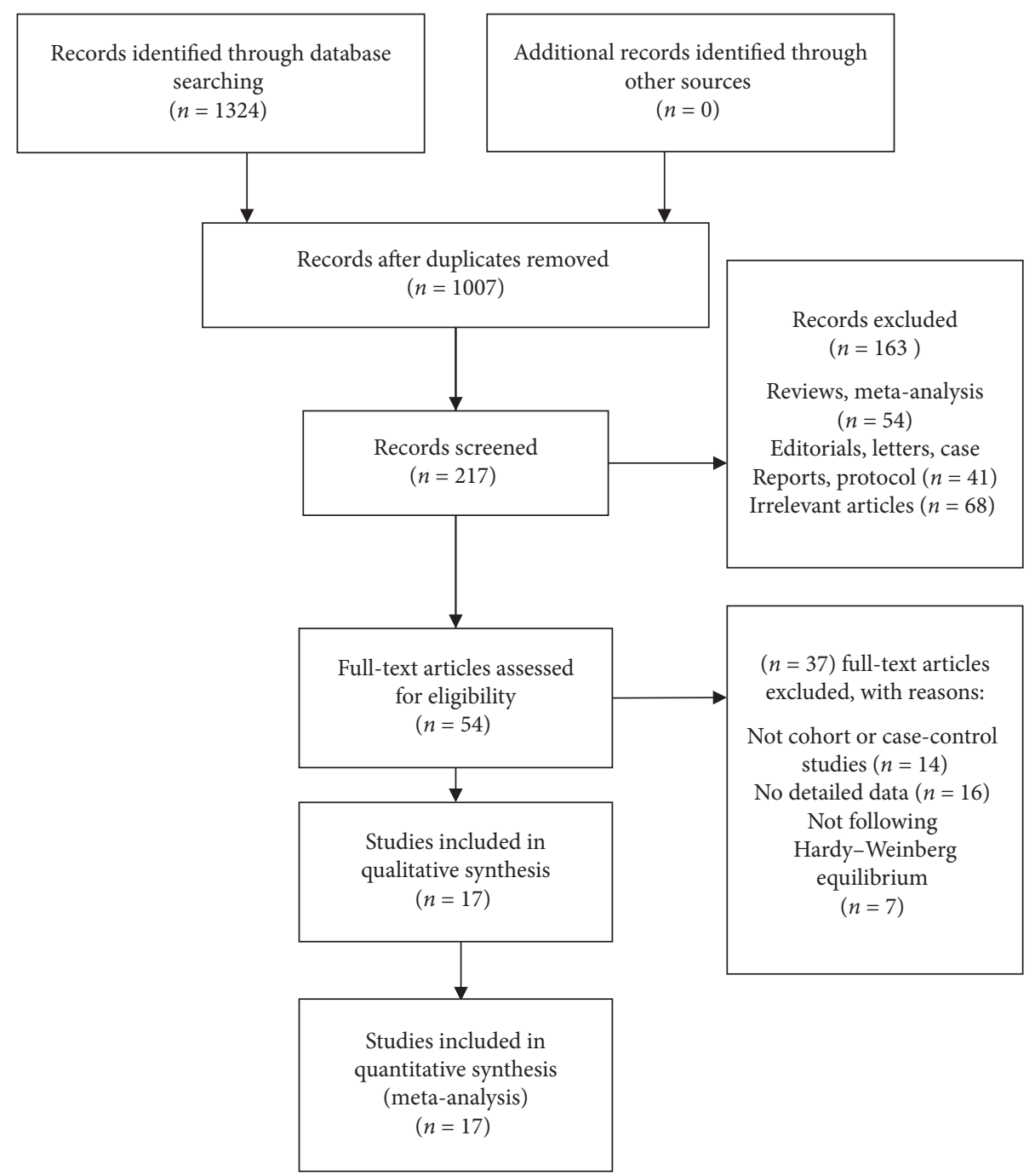

FIgURE 1: Flowchart illustrating the search strategy for IL-4-590C/T polymorphism and the risk of smoking-related cancer.

variant and the susceptibility of lung cancer, and three between IL-4-590C/T variant and the susceptibility of oral carcinoma. The others studied the association between studied IL-4-590C/T variant and the susceptibility of bladder cancer, hepatocellular cancer, and renal cell carcinoma. For genotyping methods, seven were using PCR-RFLP, six were using TaqMan, three were using PCR, and one was using MASSARRAY. The NOS scores of the 17 documents were all more than 5 , meaning that all of them were high-quality studies (Table 1).

3.2. Meta-Analysis Results. Table 2 listed the main results of the meta-analysis of IL-4-590C/T (rs2243250) gene polymorphism and the risk of smoking-related cancer in overall population. Table 3 shows the main results of subgroup analysis by ethnicity.

3.2.1. Association between IL-4-590C/T Polymorphism and the Risk of Smoking-Related Cancer. Seventeen articles including 5,061 cancer cases and 6,346 normal controls were investigated. As illustrated in Table 2, a significant relation was found for IL-4-590C/T gene polymorphism and the risk of smoking-related cancer in overall population (CT vs. TT: $P=0.026, \mathrm{OR}=0.900,95 \% \mathrm{CI}: 0.820-0.987)$. And the CT genotype carriers have a slightly lower incidence of smoking-related cancer compared to that of TT carriers and the TT variants might be a potential risk factor for smokingrelated cancer susceptibility in overall populations (Table 2 and Figure 2).

3.2.2. Association between IL-4-590C/T Polymorphism and Smoking-Related Cancer Risk in Subgroup Analysis by Ethnicity. The heterogeneity of IL-4-590C/T variant and smoking-related cancer was complicated by multiple indexes, so subgroup analysis of different ethnicities was carried out. A significant association between IL-4-590C/T variant and the susceptibility of the smoking-related cancer in Asian population (CT vs. TT: $P=0.008$, OR $=0.878,95 \%$ CI: $0.798-0.967 ; \mathrm{CC}+\mathrm{CT}$ vs. TT: $P=0.030, \mathrm{OR}=0.903,95 \%$ CI: 0.824-0.990) was found. Our results indicated that CC/ CT genotype carriers had a lower risk compared with TT 
TABLE 1: Main characters of studies included in this meta-analysis.

\begin{tabular}{|c|c|c|c|c|c|c|c|c|c|}
\hline Author & Year & Country & Ethnicity & Cancer type & $\begin{array}{l}\text { Genotyping } \\
\text { method }\end{array}$ & $\begin{array}{c}\text { Case/ } \\
n\end{array}$ & $\begin{array}{c}\text { Control/ } \\
n\end{array}$ & $P$ for $\mathrm{HWE}$ & NOS scores \\
\hline Amirzargar et al. [18] & 2005 & Iran & Caucasian & Leukemia & PCR-SSP & 30 & 40 & $P<0.05$ & 6 \\
\hline Chang et al. [19] & 2015 & China & Asian & Lung cancer & PCR-RFLP & 358 & 716 & $P<0.05$ & 8 \\
\hline Chu et al. [39] & 2012 & China & Asian & Bladder cancer & TaqMan & 816 & 1140 & 0.323 & 7 \\
\hline Chu et al. [38] & 2012 & China & Asian & Renal cell carcinoma & TaqMan & 620 & 623 & 0.079 & 7 \\
\hline Crusius et al. [26] & 2008 & Netherlands & Caucasian & Gastric cancer & PCR-RFLP & 242 & 1154 & 0.603 & 7 \\
\hline El-Omar et al.[20] & 2003 & Scotland & Mixed & Esophageal cancer & PCR-ARMS & 90 & 209 & $P<0.05$ & 6 \\
\hline El-Omar et al. [20] & 2003 & Scotland & Mixed & Gastric cancer & PCR-ARMS & 122 & 209 & $P<0.05$ & 7 \\
\hline Gaur et al. [27] & 2011 & India & Caucasian & Oral carcinoma & PCR-RFLP & 140 & 120 & 0.095 & 8 \\
\hline Gu and Shen [28] & 2014 & China & Asian & Lung cancer & TaqMan & 500 & 500 & 0.348 & 7 \\
\hline Lai et al. [29] & 2005 & China & Asian & Gastric cancer & PCR-RFLP & 123 & 162 & 0.698 & 7 \\
\hline Li et al. [21] & 2012 & China & Asian & Lung cancer & PCR-RFLP & 1072 & 1126 & $P<0.05$ & 7 \\
\hline Liang et al. [30] & 2010 & China & Asian & Gastric cancer & PCR & 238 & 112 & 0.118 & 7 \\
\hline Lu et al. [31] & 2014 & China & Asian & $\begin{array}{l}\text { Hepatocellular } \\
\text { cancer }\end{array}$ & PCR & 154 & 170 & 0.549 & 7 \\
\hline Olson et al. [22] & 2007 & USA & Mixed & Prostate cancer & PCR-RFLP & 149 & 128 & $P<0.05$ & 8 \\
\hline Pan et al. [32] & 2014 & China & Asian & Gastric cancer & PCR & 308 & 307 & 0.389 & 7 \\
\hline Saxena et al. [23] & 2014 & India & Caucasian & $\begin{array}{l}\text { Hepatocellular } \\
\text { cancer }\end{array}$ & TaqMan & 59 & 153 & $P<0.05$ & 7 \\
\hline Tsai et al. [40] & 2005 & China & Asian & Oral carcinoma & PCR-RFLP & 130 & 105 & 0.741 & 7 \\
\hline Yang et al. [33] & 2014 & China & Asian & Oral carcinoma & PCR-RFLP & 463 & 623 & 0.233 & 7 \\
\hline Zambon et al. [34] & 2008 & Italy & Caucasian & Gastric cancer & TaqMan & 40 & 64 & 0.800 & 7 \\
\hline Ando et al. [35] & 2009 & Japan & Asian & Gastric cancer & TaqMan & 330 & 190 & 0.248 & 7 \\
\hline Kesarwani et al. [24] & 2008 & India & Asian & Prostate cancer & PCR-ARMS & 200 & 200 & $P<0.05$ & 7 \\
\hline Denny et al. [36] & 2018 & Spanish & Caucasian & Gastric cancer & PCR-RFLP & 15 & 20 & 0.814 & 8 \\
\hline Tan et al. [37] & 2019 & China & Asian & Lung cancer & MASSARRAY & 199 & 266 & 0.195 & 7 \\
\hline Keith et al. [41] & 2018 & USA & Caucasian & Lung cancer & TaqMan & 616 & 616 & 0.338 & 9 \\
\hline Cozar et al. [25] & 2007 & Spain & Caucasian & Renal cell carcinoma & RCR-RFLP & 127 & 174 & 0.844 & 7 \\
\hline
\end{tabular}

$P$ for HWE: $P$ value for Hardy-Weinberg equilibrium; PCR: polymerase chain reaction; RFLP: restriction fragment length polymorphism; ARMS: amplification refractory mutation system; SSP: sequence specific primers.

TABLE 2: Meta-analysis results.

\begin{tabular}{|c|c|c|c|c|c|c|c|c|c|}
\hline \multirow[t]{2}{*}{ Contrast model } & \multirow[t]{2}{*}{ OR $(95 \% \mathrm{CI})$} & \multirow[t]{2}{*}{$P$} & \multicolumn{2}{|c|}{$\begin{array}{c}\text { Test for } \\
\text { heterogeneity }\end{array}$} & \multicolumn{2}{|c|}{$\begin{array}{l}\text { Publication } \\
\text { bias (Egger's } \\
\text { test) }\end{array}$} & \multicolumn{2}{|c|}{$\begin{array}{l}\text { Publication } \\
\text { bias (Begg's } \\
\text { test) }\end{array}$} & \multirow[t]{2}{*}{ Analysis model } \\
\hline & & & $I^{2}(\%)$ & $P$ & $t$ & $P$ & $Z$ & $P$ & \\
\hline C vs. T & $0.981(0.887,1.084)$ & 0.700 & 44.60 & 0.025 & 0.45 & 0.656 & 0.54 & 0.592 & $\mathrm{R}$ \\
\hline CC vs. TT & $1.065(0.783,1.448)$ & 0.689 & 55.30 & 0.004 & 0.35 & 0.733 & 0.68 & 0.499 & $\mathrm{R}$ \\
\hline CT vs. TT & $0.900(0.820,0.987)$ & 0.026 & 0.00 & 0.603 & 0.02 & 0.984 & 0.05 & 0.964 & $\mathrm{~F}$ \\
\hline $\mathrm{CC}+\mathrm{CT}$ vs. TT & $0.928(0.849,1.014)$ & 0.098 & 0.00 & 0.544 & 0.37 & 0.720 & 0.77 & 0.444 & $\mathrm{~F}$ \\
\hline $\mathrm{CC}$ vs. $\mathrm{TT}+\mathrm{CT}$ & $1.104(0.860,1.416)$ & 0.438 & 59.20 & 0.001 & 0.97 & 0.348 & 0.70 & 0.484 & $\mathrm{R}$ \\
\hline
\end{tabular}

R: random effect model; F: fixed-effect model; OR: odds ratio; CI: confidence interval.

carriers and the CC/CT variant might be a protective factor for smoking-related cancer susceptibility in Asian population. However, any association between smoking-related cancer risk and IL-4-590C/T variant was found in Caucasians (Table 3 ).

3.2.3. Association between Smoking-Related Cancer Susceptibility and IL-4-590C/T Polymorphism in Subgroup Analysis by Cancer Type. Our results demonstrated that IL-4-590C/T polymorphism had a lower risk for renal cell cancer (CC vs. TT: $P=0.046, \mathrm{OR}=0.640,95 \% \mathrm{CI}: 0.412-0.993)$. And the $\mathrm{CC}$ genotype might be a protective factor in renal cell cancer.
However, for bladder cancer, gastric cancer, oral carcinoma, lung cancer, and hepatocellular cancer, we did not find any obvious association in different genotype carriers (Figure 3 ).

3.3. Sensitivity Analysis. Sensitivity analysis was performed by deleting a study one by one, and the combined results showed no significant changes, denoting that the results of this study were relatively steady (Figure 4).

3.4. Publication Bias. Publication bias was evaluated by Begg's funnel plots and Egger's test (the allelic contrast of 
TABLe 3: Subgroup meta-analysis by ethnicity of IL-4 rs2243250.

\begin{tabular}{|c|c|c|c|c|c|c|}
\hline \multirow[t]{2}{*}{ Subgroup } & \multirow[t]{2}{*}{ Contrast model } & \multirow[t]{2}{*}{ OR (95\% CI) } & \multirow[t]{2}{*}{$P$} & \multicolumn{2}{|c|}{$\begin{array}{c}\text { Test for } \\
\text { heterogeneity }\end{array}$} & \multirow[t]{2}{*}{ Analysis mode } \\
\hline & & & & $I^{2}(\%)$ & $P$ & \\
\hline \multirow{5}{*}{ Asian } & $\mathrm{C}$ vs. $\mathrm{T}$ & $0.947(0.877,1.023)$ & 0.168 & 28.40 & 0.175 & $\mathrm{~F}$ \\
\hline & CC vs. TT & $1.047(0.698,1.571)$ & 0.825 & 64.90 & 0.001 & $\mathrm{R}$ \\
\hline & CT vs. TT & $0.878(0.798,0.967)$ & 0.008 & 0.00 & 0.806 & $\mathrm{~F}$ \\
\hline & $\mathrm{CC}+\mathrm{CT}$ vs. TT & $0.903(0.824,0.990)$ & 0.030 & 0.00 & 0.909 & $\mathrm{~F}$ \\
\hline & CC vs. TT + CT & $1.097(0.726,1.658)$ & 0.659 & 67.10 & 0.001 & $\mathrm{R}$ \\
\hline \multirow{5}{*}{ Caucasian } & C vs. T & $1.124(0.858,1.471)$ & 0.397 & 59.90 & 0.029 & $\mathrm{R}$ \\
\hline & CC vs. TT & $1.113(0.763,1.624)$ & 0.580 & 19.70 & 0.289 & $\mathrm{~F}$ \\
\hline & CT vs. TT & $1.259(0.875,1.813)$ & 0.215 & 0.00 & 0.487 & $\mathrm{~F}$ \\
\hline & $\mathrm{CC}+\mathrm{CT}$ vs. TT & $1.341(0.948,1.897)$ & 0.097 & 11.40 & 0.341 & $\mathrm{~F}$ \\
\hline & $\mathrm{CC}$ vs. $\mathrm{TT}+\mathrm{CT}$ & $1.046(0.882,1.241)$ & 0.605 & 42.70 & 0.121 & $\mathrm{~F}$ \\
\hline
\end{tabular}

R: random effect model; F: fixed-effect model; OR: odds ratio; CI: confidence interval.

pooled analysis: Egger's test, $P=0.656$; Begg's test, $P=0.592)$, and the $P$ value of Egger's test and Begg's test were all more than 0.05 , suggesting that there was no publication bias for the association between IL-4 rs2243250 variant and the susceptibility of smoking-related cancer in these included studies (Table 2 and Figure 5).

\section{Discussion}

In terms of originality, our meta-analysis is the first paper to study the relationship between IL-4-590C/T (rs2243250) polymorphism and smoking-related cancer. We use five genetic models ((1) allele model; (2) dominant model; (3) codominant model; (4) homozygote model; (5) recessive model) to determine the association between IL-4-590C/T (rs2243250) polymorphism and smoking-related cancer. As a result, we found that IL-4-590C/T (rs2243250) polymorphism was associated with the decreased risk of smoking-related cancer in overall population. A slightly lower incidence of smoking-related cancer was observed in CT carriers compared to TT carriers and the TT variant might be a risk factor resulting in smoking-related cancer susceptibility in different races.

In subgroup analysis by ethnicity, our results indicated that the polymorphism of IL-4-590C/T was associated with the decreased risk of smoking-related tumors in Asian population. The CT/CC genotype was a protective factor for the susceptibility of smoking-related cancer while the TT genotype was a risk factor for smoking-related cancer susceptibility. No obvious association was observed in the population of Caucasians. It might account for that genetic polymorphisms are greatly different in various racial groups, which means that we can pay more attention to IL4-590C/T gene polymorphism when screening for smoking-related cancer, especially among Asians.

For cancer-type subgroup analysis, the susceptibility of renal cell carcinoma was observed to be associated with the polymorphism of IL-4-590C/T. And the CC genotype might be a protective factor in renal cell cancer.

Our results were consistent with Chu et al. [38]; they found that the polymorphism of IL-4 rs2243250 was also associated with the lower risk of renal cell carcinoma. But our result was different from Cozar et al. [25]; they did not find that the polymorphism of IL-4 rs2243250 was also associated with the susceptibility of renal cell carcinoma. In addition, Pan et al. [32] and Tan et al. [37] have found that IL-4-590C/T variant was relevant with the increased risk of lung cancer and gastric cancer. The possible reasons for the different results of the above studies have been summarized as follows: (1) the genetic background of the population was different; (2) the sample volume of Asians we included in this meta-analysis was much larger than that of Caucasians; (3) the methods of genotyping were different in these included studies; (4) the different types of smoking-related cancers had different relationships with IL-4 rs2243250 polymorphism. In addition, IL-4 rs2243250 polymorphism was involved in the metabolism of a variety of carcinogens associated with tobacco smoke, which may be affected by complex factors like multiple genes, environmental factors, individual genetic background, and dietary habits.

Some advantages feature our findings. First, we performed the NOS quality test on all the included literature, ensuring that the literature works included were of high quality. Second, HWE tests were conducted on included documents, and we excluded those that did not meet the Hardy-Weinberg Equilibrium. Third, more than 11,407 subjects consisting of 5,061 patients with smoking-related cancer and 6,346 controls were contained in the study. Therefore, the sample size was large enough to confirm the results of our analysis. Moreover, sensitivity analysis and Egger's test showed the results were stable.

One of the important things about meta-analysis is heterogeneity, and ignoring the heterogeneity may lead to scientific errors. We found the heterogeneity was significant in many models. Therefore, we conducted a subgroup analysis and finally found that the type of cancer may be the source of this heterogeneity.

There are still some limitations in this study that cannot be avoided. Firstly, some of the included studies show lack of enough original information like smoking history and family conditions. So it cannot be assessed for potential interactions with interference factors. Besides, the present meta-analysis 


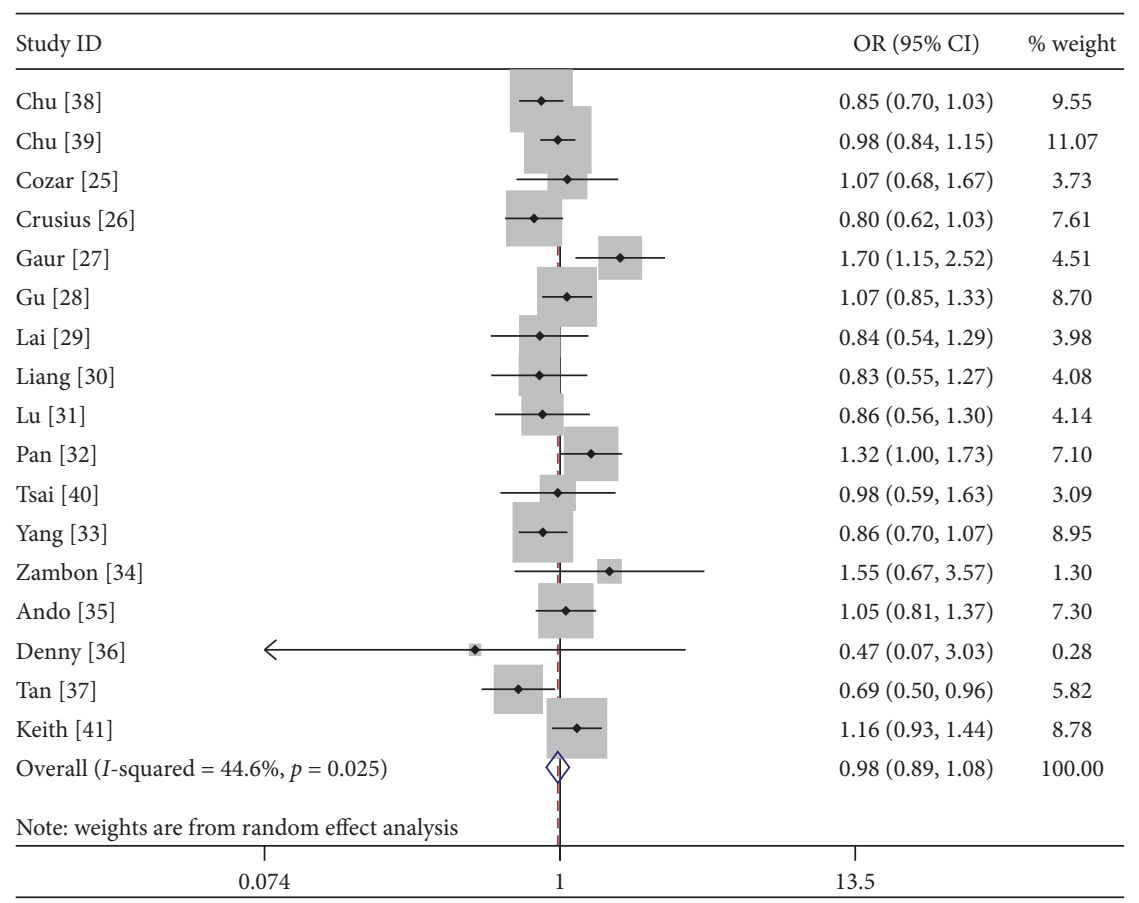

(a)

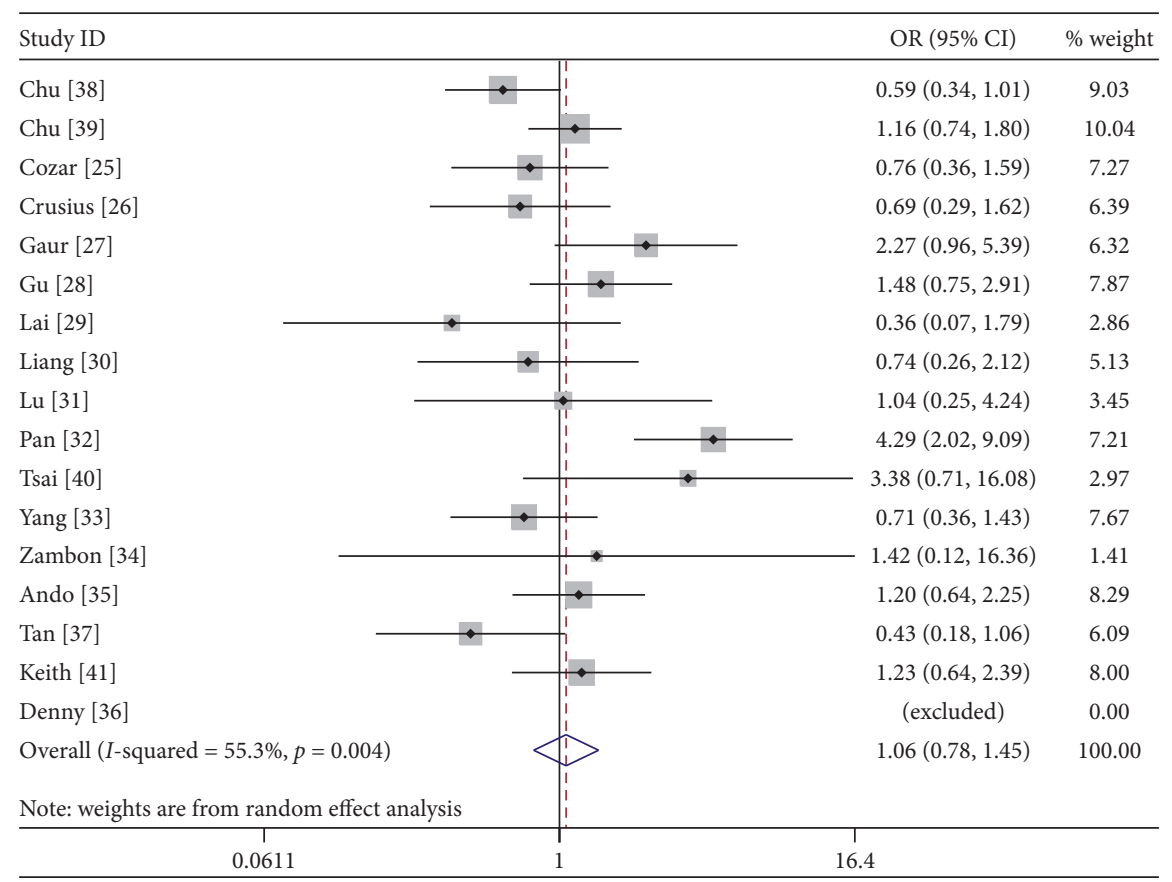

(b)

Figure 2: Continued. 


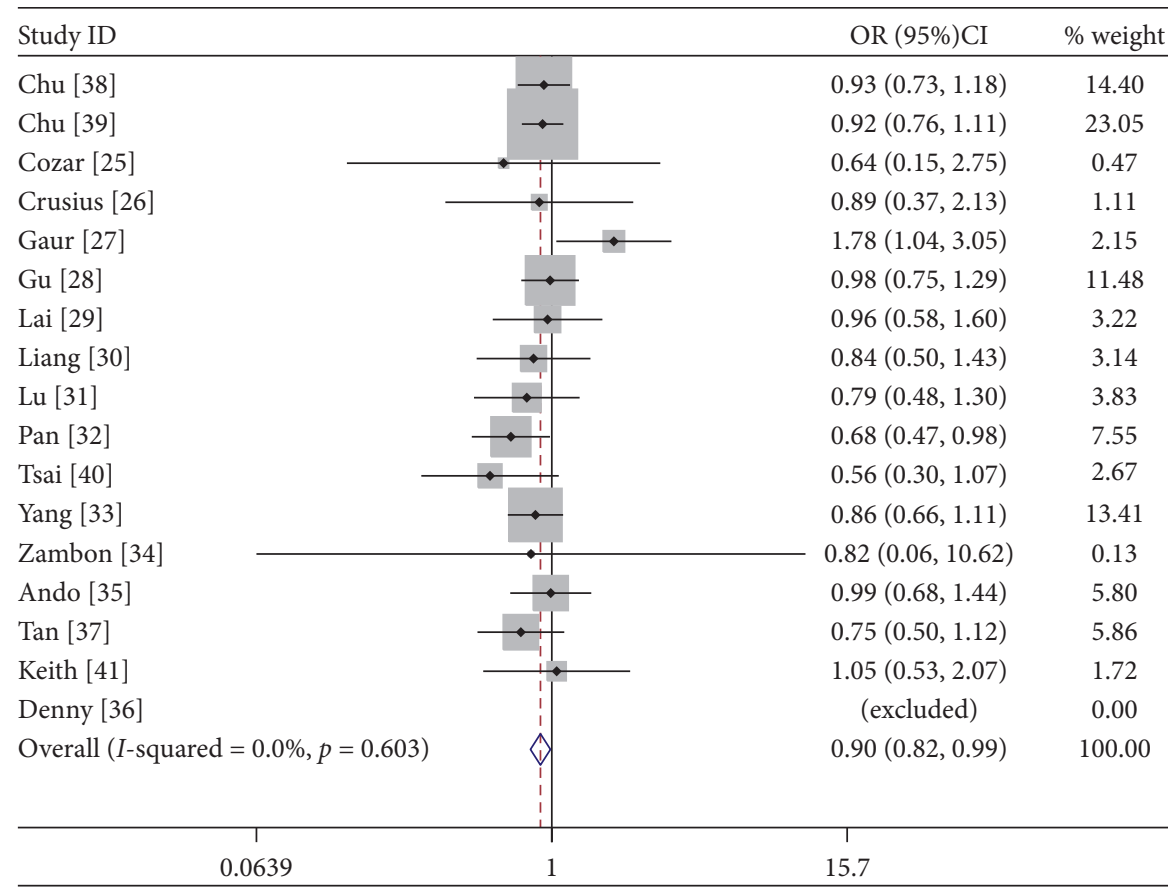

(c)

\begin{tabular}{|c|c|c|c|}
\hline \multicolumn{2}{|l|}{ Study ID } & \multirow{2}{*}{$\frac{\mathrm{OR}(95 \% \mathrm{CI})}{0.88(0.69,1.10)}$} & \multirow{2}{*}{$\begin{array}{c}\% \text { weigh } \\
15.09\end{array}$} \\
\hline Chu [38] & $\rightarrow$ & & \\
\hline Chu [39] & $\rightarrow$ & $0.94(0.78,1.14)$ & 22.86 \\
\hline Cozar [25] & & $0.72(0.18,2.95)$ & 0.45 \\
\hline Crusius [26] & $\longrightarrow$ & $0.74(0.32,1.74)$ & 1.12 \\
\hline Gaur [27] & $\longrightarrow$ & $1.88(1.14,3.10)$ & 2.25 \\
\hline $\mathrm{Gu}[28]$ & $\rightarrow$ & $1.03(0.79,1.33)$ & 11.22 \\
\hline Lai [29] & $\cdot$ & $0.89(0.54,1.46)$ & 3.30 \\
\hline Liang [30] & $\cdot-$ & $0.83(0.50,1.36)$ & 3.37 \\
\hline $\mathrm{Lu}[31]$ & 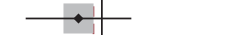 & $0.81(0.50,1.30)$ & 3.74 \\
\hline Pan [32] & $\rightarrow$ & $0.98(0.70,1.37)$ & 7.04 \\
\hline Tsai $[40]$ & $\longrightarrow+1$ & $0.75(0.42,1.35)$ & 2.53 \\
\hline Yang [33] & 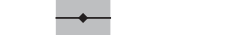 & $0.85(0.66,1.09)$ & 13.30 \\
\hline Zambon [34] & $\frac{11}{11} \cdot$ & $-1.26(0.11,14.34)$ & 0.12 \\
\hline Ando [35] & $\longrightarrow$ & $1.02(0.71,1.47)$ & 5.75 \\
\hline Tan [37] & $\longrightarrow$ & $0.69(0.47,1.02)$ & 6.22 \\
\hline Keith [41] & $:$ & $1.18(0.61,2.28)$ & 1.63 \\
\hline Denny [36] & $\begin{array}{l}1 \\
1 \\
1\end{array}$ & (excluded) & 0.00 \\
\hline Overall $(I$-squared $=0.0 \%, p=0.544)$ & (1) & $0.93(0.85,1.01)$ & 100.00 \\
\hline $\begin{array}{c} \\
0.0697\end{array}$ & 1 & $\begin{array}{c}1 \\
14.3\end{array}$ & \\
\hline
\end{tabular}

(d)

Figure 2: Continued. 


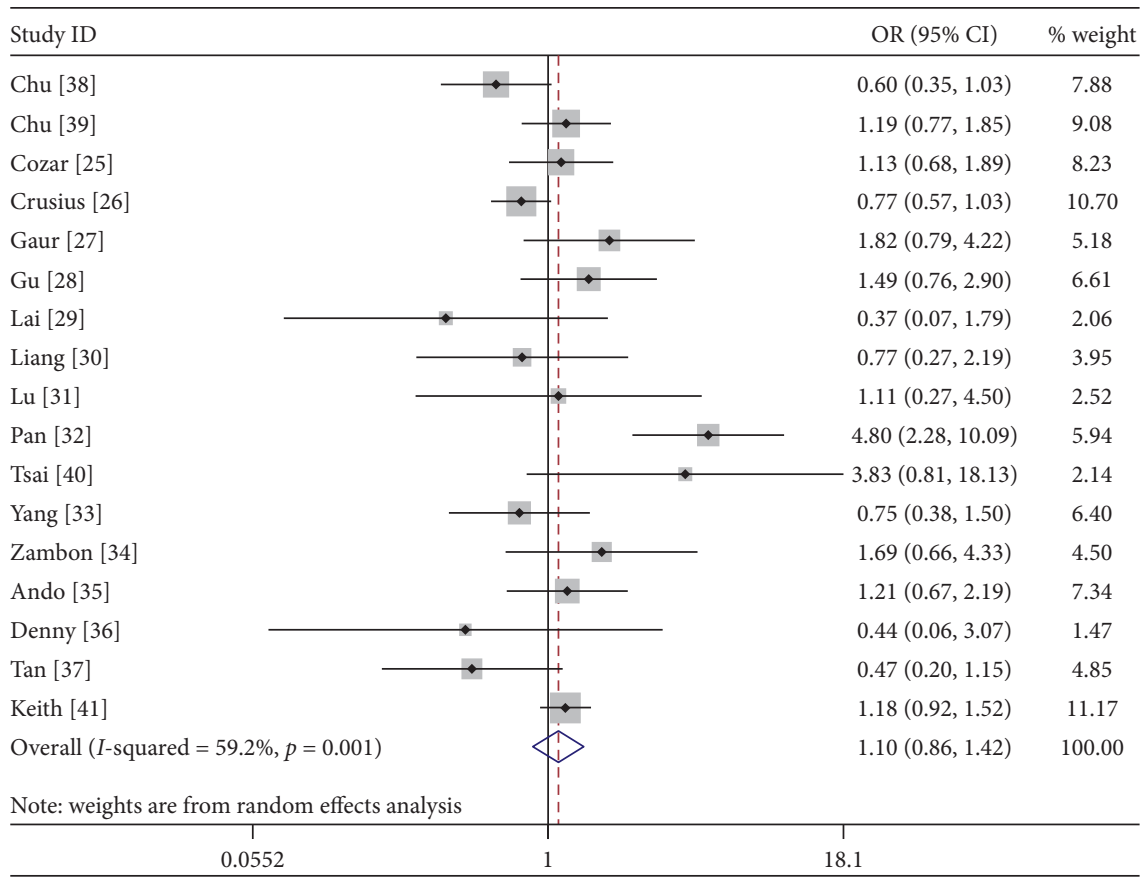

(e)

Figure 2: Forest plot of association between IL-4-590C/T polymorphism and smoking-related cancer in overall population ((a) C allele vs. T allele; (b) CC vs. TT; (c) CT vs. TT; (d) CC + CT vs. TT; (e) CC vs. CT + TT).

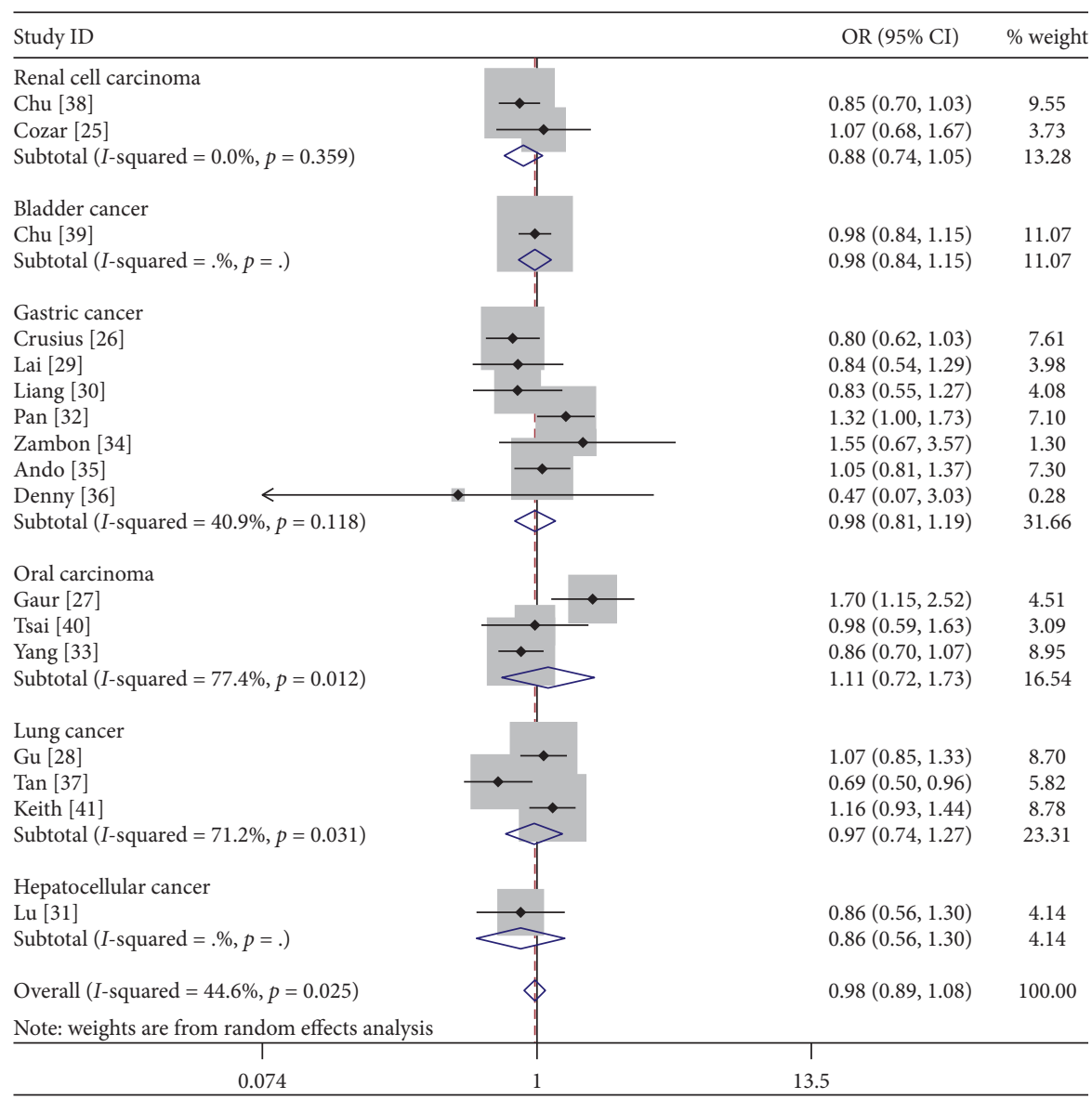

(a)

Figure 3: Continued. 


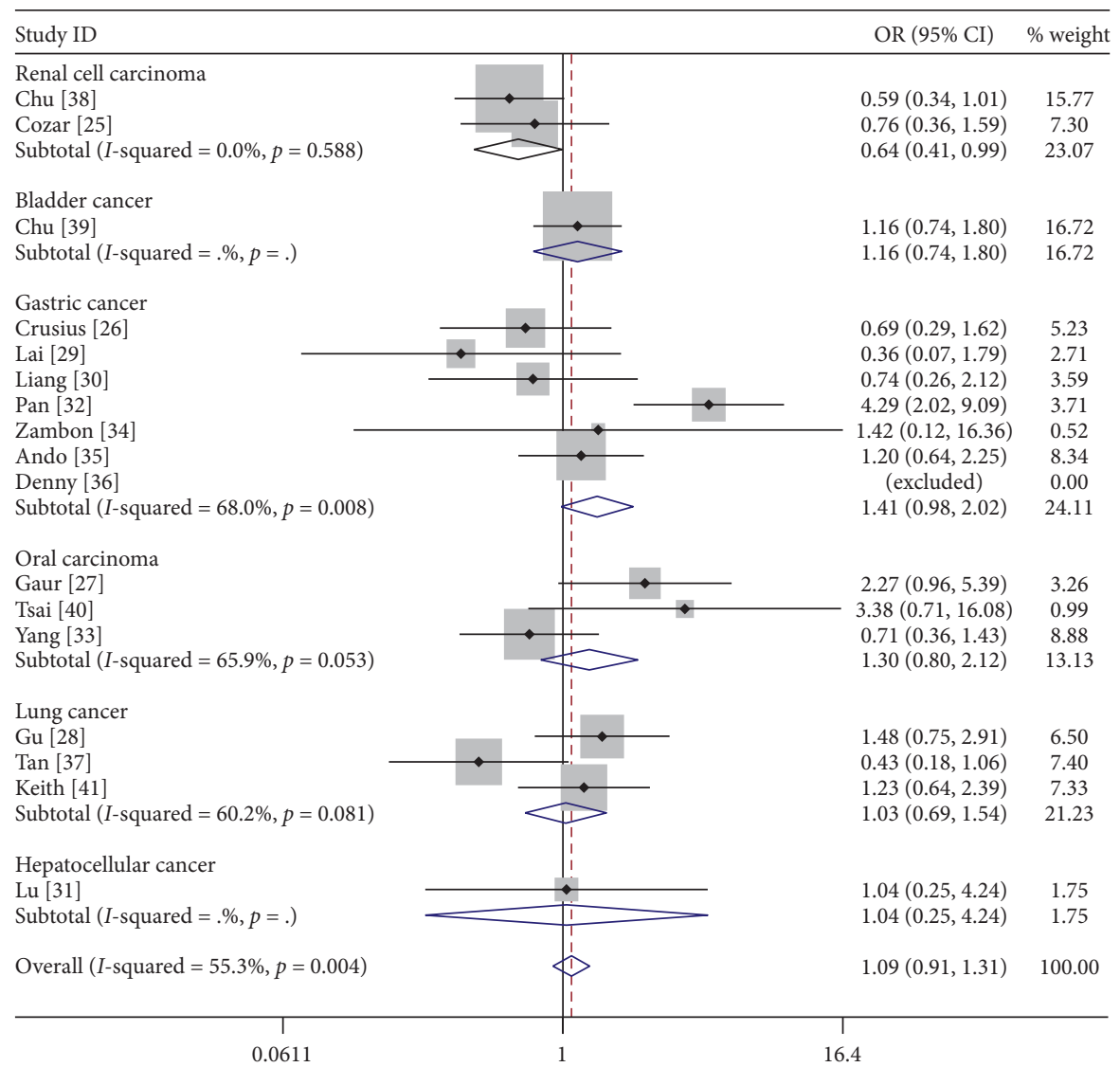

(b)

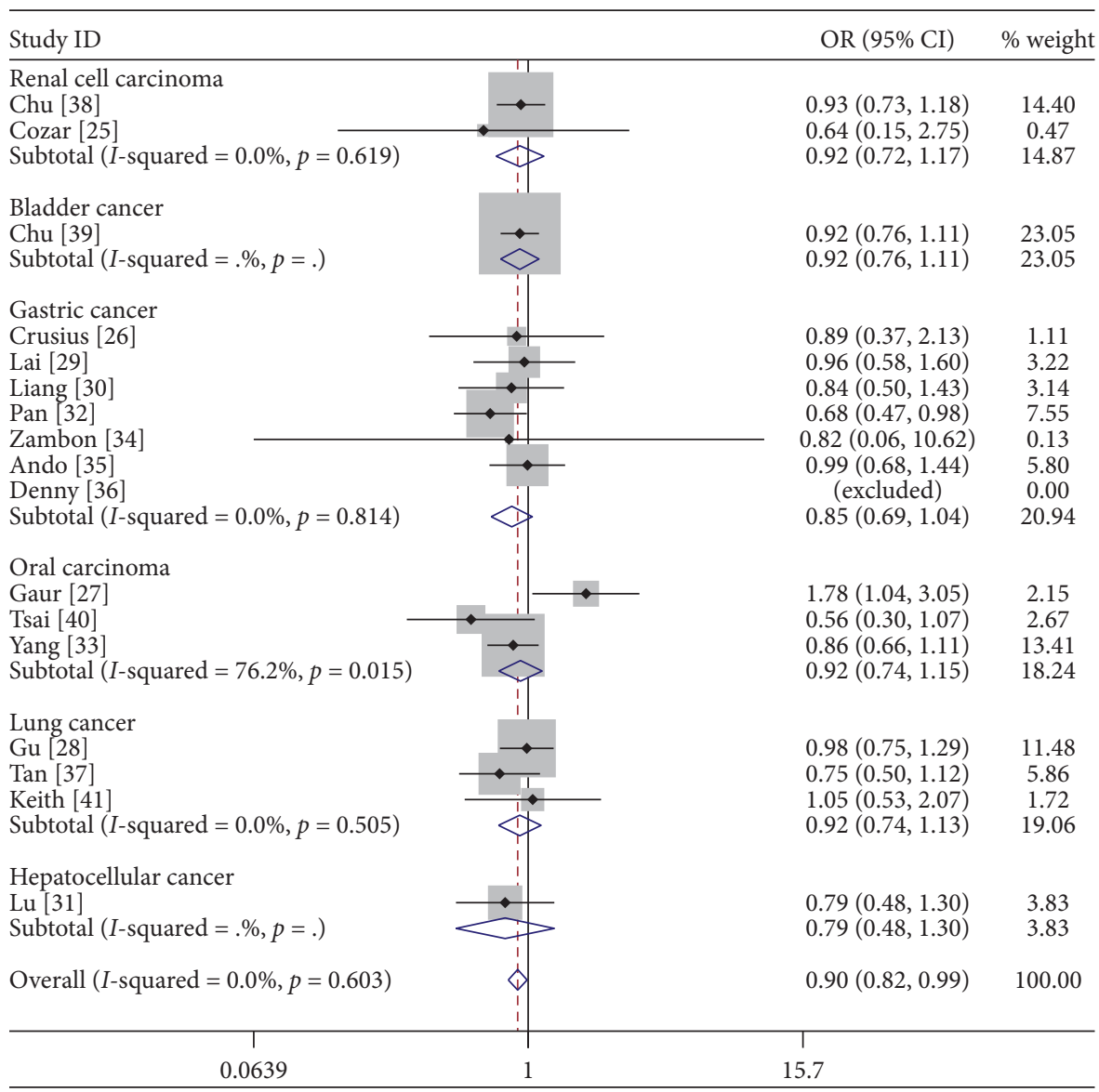

(c)

Figure 3: Continued. 


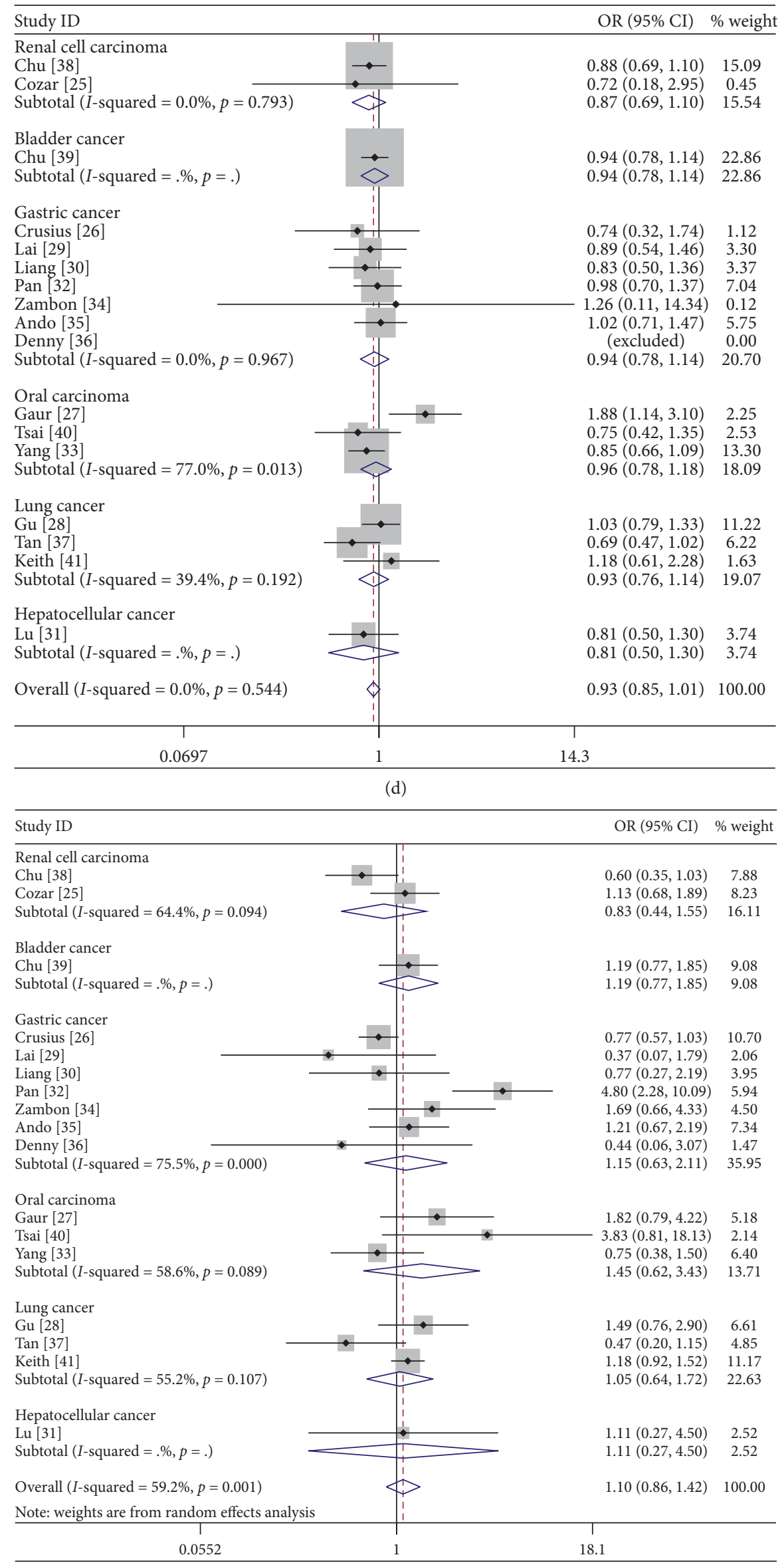

(e)

FIgURe 3: Forest plot of subgroup analysis by cancer type ((a) C allele vs. Tallele; (b) CC vs. TT; (c) CT vs. TT; (d) CC + CT VS. TT; (e) CC vs. CT + TT). 


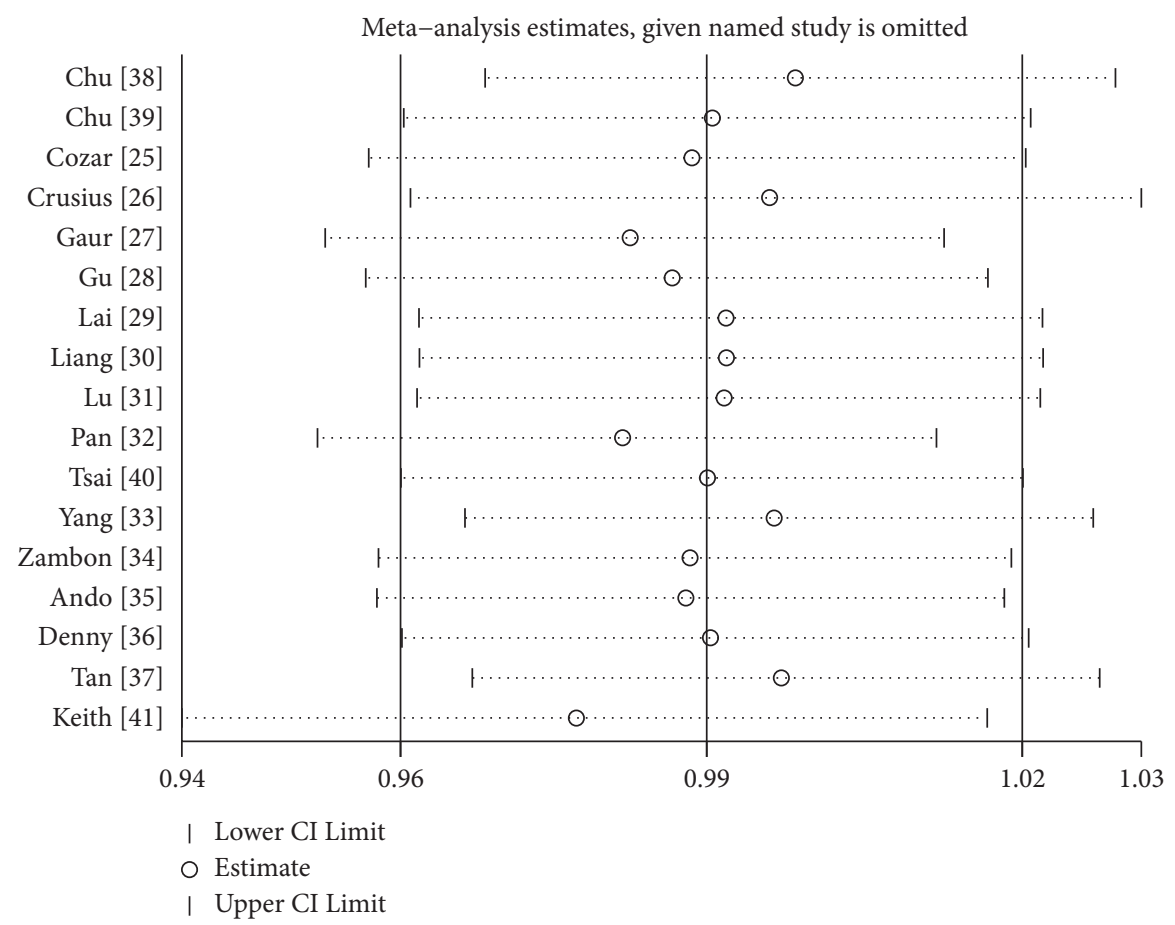

FIGURE 4: Sensitivity analysis of the pooled ORs and 95\% CIs for IL-4-590C/T polymorphism (C allele vs. T allele).

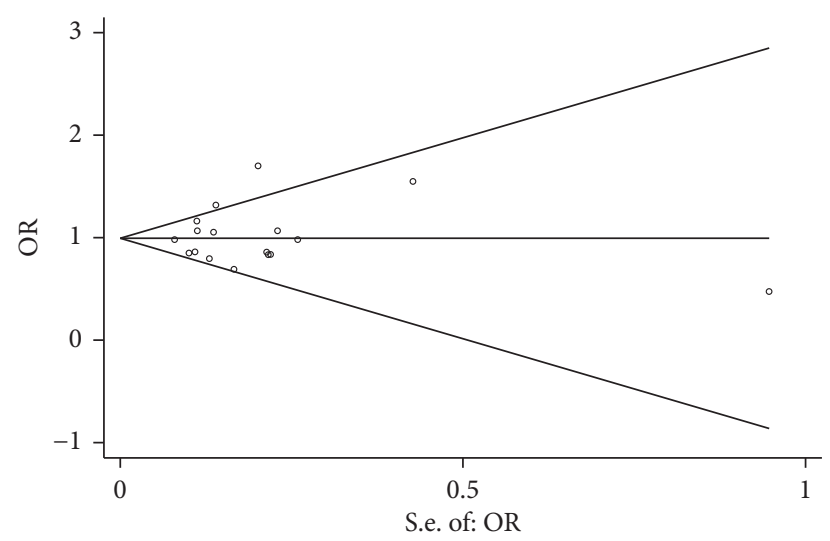

Figure 5: Begg's funnel plot with pseudo 95\% confidence limits for studies of the association between smoking-related cancer risk and IL-4590C/T polymorphism (C allele vs. T allele).

only included English and Chinese studies, so it might cause language bias. Therefore, there is a need for more multicentric researches with large samples to be carried out in future to gain more insights into the association between IL-4 rs2243250 polymorphism and smoking-related cancer.

\section{Conclusion}

Our study indicates that smoking-related cancer susceptibility is associated with IL-4-590C/T polymorphism in the total population. The CT genotype carriers have a slightly lower incidence of smoking-related cancer compared to TT carriers in the overall populations. And the IL-4-590C/T polymorphism has different susceptibility to smoking-related tumors in the different populations, especially in
Asians. However, in order to determine a comprehensive conclusion on the correlation between smoking-related cancer susceptibility and IL-4-590C/T polymorphism, more prospective cohort studies are still needed in the future.
Abbreviations
OR:
Odds ratio
CI: Confidence interval
HWE: Hardy-Weinberg equilibrium
IL-4: $\quad$ Interleukin-4
SNP: $\quad$ Single nucleotide polymorphism
IARC: International Agency for Research on Cancer 
The NOS The Newcastle-Ottawa scale

scale:

R: $\quad$ Random effect model

F: $\quad$ Fixed-effect model.

\section{Disclosure}

Guangyuan Chen, Cong $\mathrm{Hu}$, and Yuxuan Song contributed equally and should be considered as the co-first authors.

\section{Conflicts of Interest}

The authors declare that they have no conflicts of interest.

\section{Authors' Contributions}

Peng Huang was responsible for study design with methodology checking and data analysis guidance. Guangyuan Chen and Cong $\mathrm{Hu}$ were involved in data collection. Guangyuan Chen, Cong Hu, Penghui Lai, and Haifei Zhang analysed the data; Guangyuan Chen, Cong $\mathrm{Hu}$, and Yuxuan Song wrote the manuscript. Yuxuan Song, Yiling Zhang, and Song Li carried out grammar checking.

\section{Acknowledgments}

The authors thank Yunyan Li, Nanchang University, the senior fellow apprentice of them, for providing valuable comments.

\section{Supplementary Materials}

PRISMA 2009 Checklist. (Supplementary Materials)

\section{References}

[1] M. P. A. Zeegers, F. E. S. Tan, E. Dorant, and P. A. van den Brandt, "The impact of characteristics of cigarette smoking on urinary tract cancer risk: a meta-analysis of epidemiologic studies," Cancer, vol. 89, no. 3, pp. 630-639, 2000.

[2] J. Lortet-Tieulent, A. Goding Sauer, R. L. Siegel et al., "Statelevel cancer mortality attributable to cigarette smoking in the United States," JAMA Internal Medicine, vol. 176, no. 12, pp. 1792-1798, 2016.

[3] S. S. Hecht, "Tobacco carcinogens, their biomarkers and tobacco-induced cancer," Nature Reviews Cancer, vol. 3, no. 10, pp. 733-744, 2003.

[4] C. J. Smith, T. A. Perfetti, R. Garg, and C. Hansch, "IARC carcinogens reported in cigarette mainstream smoke and their calculated $\log P$ values," Food and Chemical Toxicology, vol. 41, no. 6, pp. 807-817, 2003.

[5] C. J. Smith, T. A. Perfetti, M. A. Rumple, A. Rodgman, and D. J. Doolittle, “"IARC group 2B carcinogens” reported in cigarette mainstream smoke," Food and Chemical Toxicology, vol. 39, no. 9, pp. 183-205, 2001.

[6] S. S. Hecht, "Progress and challenges in selected areas of tobacco carcinogenesis," Chemical Research in Toxicology, vol. 21, no. 1, pp. 160-171, 2008.

[7] A. Besaratinia and S. Tommasi, "Genotoxicity of tobacco smoke-derived aromatic amines and bladder cancer: current state of knowledge and future research directions," The FASEB Journal, vol. 27, no. 6, pp. 2090-2100, 2013.

[8] L. Hlatky and P. Hahnfeldt, "Beyond the cancer cell: progression-level determinants highlight the multiscale nature of carcinogenesis risk," Cancer Research, vol. 74, no. 3, pp. 659-664, 2014.

[9] F. H. van Osch, S. H. Jochems, F.-J. van Schooten, R. T. Bryan, and M. P. Zeegers, "Quantified relations between exposure to tobacco smoking and bladder cancer risk: a meta-analysis of 89 observational studies," International Journal of Epidemiology, vol. 45, no. 3, pp. 857-870, 2016.

[10] C. Samanic, M. Kogevinas, M. Dosemeci et al., "Smoking and bladder cancer in Spain: effects of tobacco type, timing, environmental tobacco smoke, and gender," Cancer Epidemiology Biomarkers \& Prevention, vol. 15, no. 7, pp. 1348-1354, 2006.

[11] Y. Suwazono, K. Nogawa, M. Uetani et al., "Application of hybrid approach for estimating the benchmark dose of urinary cadmium for adverse renal effects in the general population of Japan," Journal of Applied Toxicology, vol. 31, no. 1, pp. 89-93, 2011.

[12] F. Bray, J. Ferlay, I. Soerjomataram, R. L. Siegel, L. A. Torre, and A. Jemal, "Global cancer statistics 2018: globocan estimates of incidence and mortality worldwide for 36 cancers in 185 countries," CA: A Cancer Journal for Clinicians, vol. 68, no. 10, pp. 394-424, 2018.

[13] M. L. Laine, B. G. Loos, and W. Crielaard, "Gene polymorphisms in chronic periodontitis," International Journal of Dentistry, vol. 2010, no. 10, pp. 1-22, 2010.

[14] M. Završnik, J. Letonja, J. Makuc, M. Šeruga, I. Cilenšek, and D. Petrovič, "Interleukin-4 gene (IL4)-590C/T (rs2243250) gene polymorphism is not associated with diabetic nephropathy (DN) in Caucasians with type 2 diabetes mellitus (T2DM)," Bosnian Journal of Basic Medical Sciences, vol. 26, no. 88, 2018.

[15] B. B. Aggarwal, R. V. Vijayalekshmi, and B. Sung, "Targeting inflammatory pathways for prevention and therapy of cancer: short-term friend, long-term foe," Clinical Cancer Research, vol. 15, no. 2, pp. 425-430, 2009.

[16] J. Teler, M. Tarnowski, K. Safranow et al., "CCL2, CCL5, IL4 and IL15 gene polymorphisms in women with gestational diabetes mellitus," Hormone \& Metabolic Research, vol. 49, no. 1, pp. 10-15, 2017.

[17] H.-W. Wang and J. A. Joyce, "Alternative activation of tumorassociated macrophages by IL-4: priming for protumoral functions," Cell Cycle, vol. 9, no. 24, pp. 4824-4835, 2010.

[18] A. A. Amirzargar, M. Bagheri, A. Ghavamzadeh et al., "Cytokine gene polymorphism in Iranian patients with chronic myelogenous leukaemia," International Journal of Immunogenetics, vol. 32, no. 3, pp. 167-171, 2005.

[19] W. S. Chang, S. C. Wang, C. L. Chuang et al., "Contribution of interleukin-4 genotypes to lung cancer risk in Taiwan," $A n$ ticancer Research, vol. 3, no. 11, pp. 6297-6301, 2015.

[20] E. M. El-Omar, C. S. Rabkin, M. D. Gammon et al., "Increased risk of noncardia gastric cancer associated with proinflammatory cytokine gene polymorphisms," Gastroenterology, vol. 124, no. 5, pp. 1193-1201, 2003.

[21] X. Li, W. Shi, G. Yu et al., "Interleukin-4 -590T/C polymorphism influences the susceptibility to nonsmall cell lung cancer," DNA and Cell Biology, vol. 31, no. 5, pp. 797-800, 2012.

[22] S. H. Olson, I. Orlow, J. Simon et al., "Allergies, variants in IL4 and IL-4R $\alpha$ genes, and risk of pancreatic cancer," Cancer Detection and Prevention, vol. 31, no. 2, pp. 345-351, 2007. 
[23] R. Saxena, Y. K. Chawla, I. Verma, and J. Kaur, "Effect of IL12B, IL-2, TGF- $\beta 1$, and IL-4 polymorphism and expression on hepatitis B progression," Journal of Interferon \& Cytokine Research, vol. 34, no. 2, pp. 117-128, 2014.

[24] P. Kesarwani, D. K. Ahirwar, A. Mandhani, and R. D. Mittal, "Association between $-174 \mathrm{G} / \mathrm{C}$ promoter polymorphism of the interleukin- 6 gene and progression of prostate cancer in north Indian population," DNA and Cell Biology, vol. 27, no. 9, pp. 505-510, 2008.

[25] J. M. Cozar, J. M. Romero, N. Aptsiauri et al., "High incidence of CTLA-4 AA (CT60) polymorphism in renal cell cancer," Human Immunology, vol. 68, no. 8, pp. 698-704, 2007.

[26] J. B. Crusius, F. Canzian, G. Capellá et al., "Cytokine gene polymorphisms and the risk of adenocarcinoma of the stomach in the European prospective investigation into cancer and nutrition (EPIC-EURGAST)," Annals of Oncology, vol. 19, no. 11, pp. 1894-1902, 2008.

[27] P. Gaur, M. Mittal, B. K. Mohanti, and S. N. Das, "Functional variants of IL4 and IL6 genes and risk of tobacco-related oral carcinoma in high-risk Asian Indians," Oral Diseases, vol. 17, no. 7, pp. 720-726, 2011.

[28] J. Gu and Y. Shen, "Association between interleukin-4 polymorphisms and environment and nonsmall cell lung cancer in Chinese population," Journal of Cancer Research and Therapeutics, vol. 10, no. 7, pp. 135-139, 2014.

[29] K.-C. Lai, W.-C. Chen, L.-B. Jeng, S.-Y. Li, M.-C. Chou, and F.-J. Tsai, "Association of genetic polymorphisms of MK, IL-4, p16, p21, p53 genes and human gastric cancer in Taiwan," European Journal of Surgical Oncology (EJSO), vol. 31, no. 10, pp. 1135-1140, 2005.

[30] X. L. Liang, H. B. Hu, and A. P. Jia, "Association of PTPN11 and interleukin-4 gene polymorphisms and helicobacter pylori infection with susceptibility to gastric cancer," Hai Nan Yi Xue, vol. 20, no. 10, pp. 1-5, 2010, in Chinese.

[31] Y. Lu, Z. Wu, Q. Peng et al., "Role of IL-4 gene polymorphisms in HBV-related hepatocellular carcinoma in a Chinese population," PLoS One, vol. 9, no. 10, Article ID e110061, 2014.

[32] X.-F. Pan, Y. Wen, M. Loh et al., "Interleukin-4 and -8 gene polymorphisms and risk of gastric cancer in a population in Southwestern China," Asian Pacific Journal of Cancer Prevention, vol. 15, no. 7, pp. 2951-2957, 2014.

[33] C.-M. Yang, H.-C. Chen, Y.-Y. Hou et al., "A high IL-4 production diplotype is associated with an increased risk but better prognosis of oral and pharyngeal carcinomas," Archives of Oral Biology, vol. 59, no. 1, pp. 35-46, 2014.

[34] C. F. Zambon, D. Basso, A. Marchet et al., "IL-4 -588C>T polymorphism and IL-4 receptor alpha $[\mathrm{Ex} 5+14 \mathrm{~A}>\mathrm{G}$; Ex11+828A $>$ G] haplotype concur in selecting H. pylori cagA subtype infections," Clinica Chimica Acta, vol. 389, no. 1-2, pp. 139-145, 2008.

[35] T. Ando, T. Ishikawa, H. Kato et al., "Synergistic effect of HLA class II loci and cytokine gene polymorphisms on the risk of gastric cancer in Japanese patients with Helicobacter pylori infection," International Journal of Cancer, vol. 125, no. 11, pp. 2595-2602, 2009.

[36] C. M. Denny, A. C. Sánchez, and D. A. Rosas, "Preliminary analysis of single-nucleotide polymorphisms in IL-10, IL-4, and IL-4R $\alpha$ genes and profile of circulating cytokines in patients with gastric cancer," BMC Gastroenterology, vol. 18, no. 1, pp. 184-186, 2018.

[37] N. Tan, J. Song, M. Yan et al., “Association between IL-4 tagging single nucleotide polymorphisms and the risk of lung cancer in China," Molecular Genetics \& Genomic Medicine, vol. 7, no. 4, Article ID e00585, 2019.

[38] H. Chu, M. Wang, F. Yan et al., "Polymorphisms in the IL-13 and IL-4R genes are associated with the development of renal cell carcinoma," Annals of Oncology, vol. 23, no. 8, pp. 2114-2121, 2012.

[39] H. Chu, L. Ma, M. Wang et al., "The polymorphisms of IL-4, IL-4R and IL-13 genes and bladder cancer risk in a Chinese population: a case-control study," Molecular Biology Reports, vol. 39, no. 5, pp. 5349-5357, 2012.

[40] M. H. Tsai, W. C. Chen, C. H. Tsai, L.-W. Hang, and F.-J. Tsai, "Interleukin-4 gene, but not the interleukin-1 beta gene polymorphism, is associated with oral cancer," Journal of Clinical Laboratory Analysis, vol. 19, no. 3, pp. 93-98, 2005.

[41] E. D. Keith, P. E. Romine, G. E. Goodman, M. D. Thornquist, M. J. Barnett, and E. W. Petersdorf, "Inflammatory gene polymorphisms in lung cancer susceptibility," Journal of Thoracic Oncology, vol. 13, no. 5, pp. 649-659, 2018. 


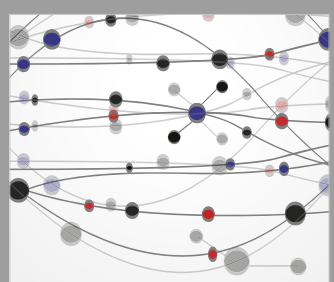

The Scientific World Journal
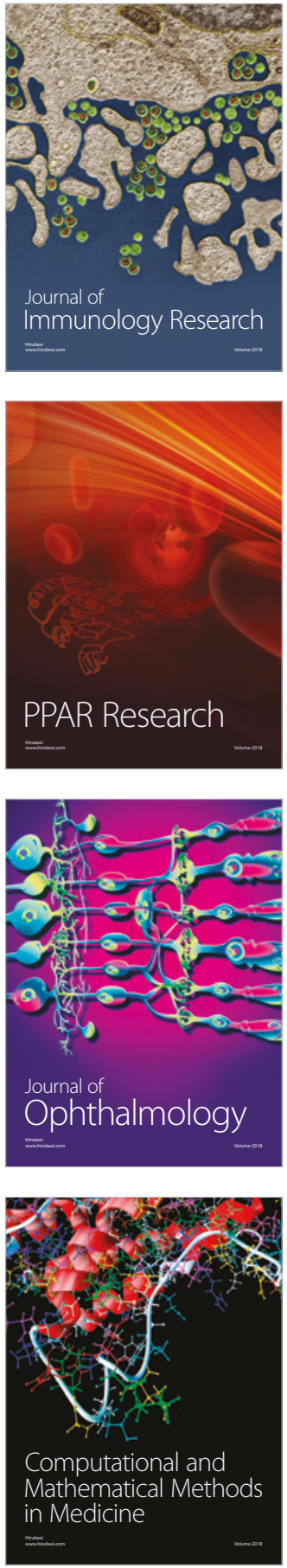

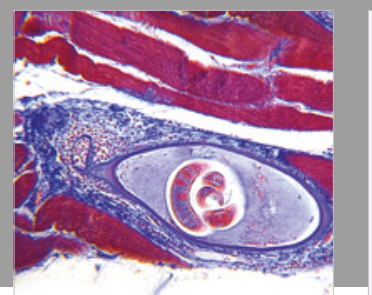

Gastroenterology Research and Practice

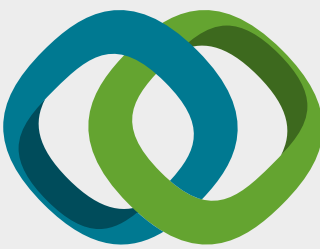

\section{Hindawi}

Submit your manuscripts at

www.hindawi.com
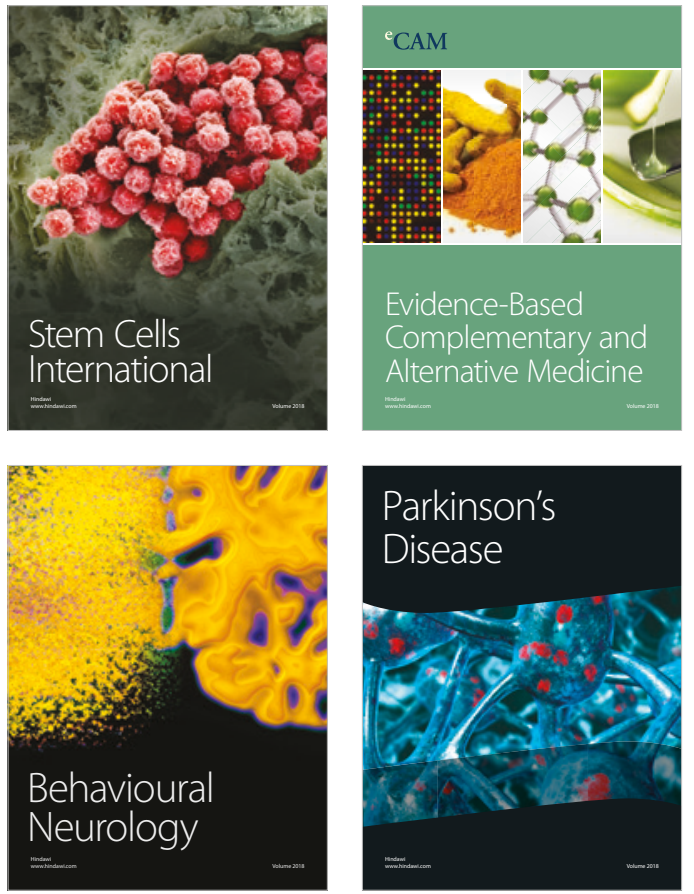

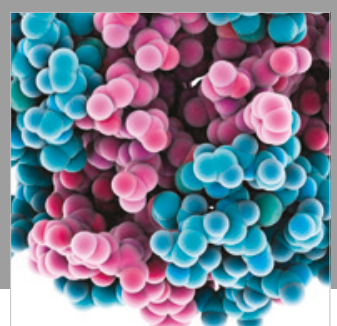

ournal of

Diabetes Research

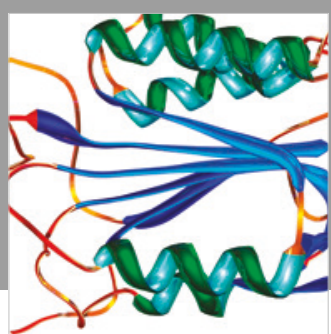

Disease Markers
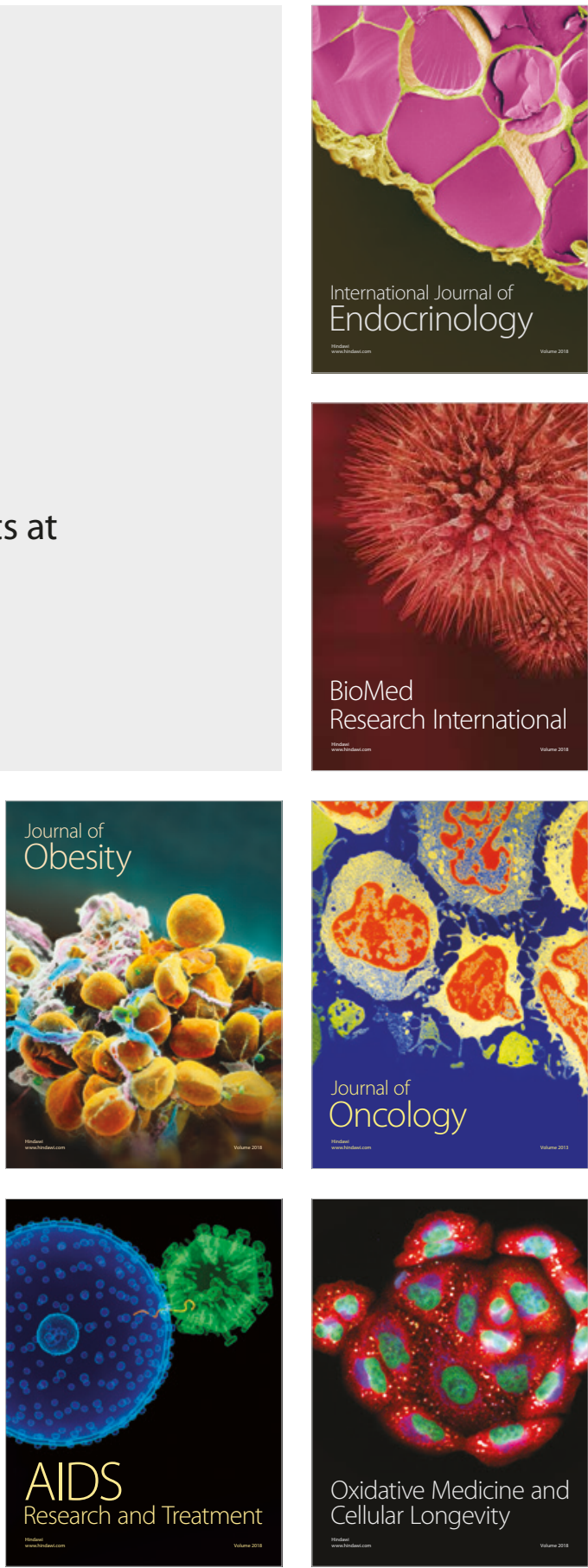